\title{
Exclusion of Illegally Obtained Evidence in China: from the Perspective of Undue Coercion
}

\author{
Jiang $\mathrm{Na}^{1 *}$ and Han Rong ${ }^{2}$ \\ ${ }^{1}$ Department of Criminal Law Science, China \\ ${ }^{2}$ Law School of Beijing Normal University, China
}

*Corresponding author: Jiang $\mathrm{Na}$, Department of Criminal Law Science, China.

Received Date: November 26, 2018

Published Date: December 05, 2018

\section{Introduction}

China has introduced exclusionary rules in the 2012 Criminal Procedure Law (CPL) by means of new justice reforms. Some reformers hold that China protects and ensures the accused's rights to remain silent or privilege against self-incrimination, based on the new rule of excluding illegally obtained evidence in the CPL. Differently, some argue against them that China cannot actually exclude all forms of illegally obtained evidence, particularly evidence extorted through undue pressure or coercion, which is at the core of reasons leading to injustices in practice. It is very necessary for more reformers to focus on such evidence from a new perspective of undue coercion, in order to fill in the gap between the above actual needs and legal requirements.

\section{Right to Remain Silent and Privilege against Self- Incrimination}

The both differ in many aspects, particularly in the cases of undue coercion. In PRC's criminal justice system, there is the "red line" drawn when fact-finding is deemed invasive with regard to individual rights, but not a clear definition of undue coercion. In fact, the accused have no legal right to remain silent during interviews or interrogations in the criminal process, and only have the legal privilege against self-incrimination at a very basic level, as implied in Art. 50 of the 2012 CPL.

\section{Exclusionary Rules for Illegally Gathered Evidence in Cases of Undue Coercion (other than torture)}

Concerning the legal framework of exclusionary rules, there are some statutory rules governing the exclusion process of evidence in the cases of possible undue coercion and of torture as explicitly prohibited by the CPL in China. Justifications for the exclusionary rules according to the law on the books are diverse in China. They are mainly related to safeguarding the respect for human rights and criminal justice.

The exclusion of witness testimony collected by illegal means is mandatory in the cases of undue coercion and the exclusion of material or documentary evidence collected by such means is discretionary, as showed in Art. 40 of the 2012 CPL. By the law, there are also some exceptions to the above principle of mandatory exclusion.

In practice, courts hardly recognize the general "exclusionary rule" in cases of undue coercion in order to control crime. But they often read the duty to find the truth into specific rules, so as to overrule explicit or implied exclusionary rules against law.

\section{More Obstacles to Excluding All of Illegally obtained Evidence in China}

Apart from a lack of explicit exclusion of illegally obtained evidence in the cases of undue coercion, more obstacles persist in fact, so that China cannot exclude it from use in conviction or sentencing. They mainly include several aspects as follows:

Firstly, there is no institutional arrangement safeguarding the right to silence. Given the common goal of crime control, the authorities have no interest in limiting fact-finding. Secondly, the admissibility of indirect evidence or "fruits of poisonous tree" in cases of undue coercion is not yet a part of China's criminal justice reforms. In legislation, its criminal justice system does address the problem of indirect evidence gained through evidence obtained by undue coercion, but not acknowledge a "fruit of the poisonous tree" doctrine in any statutory rules. Hence, there is no legal framework on the admissibility of indirect evidence in the cases of undue correction. Also, there is no clear justification for the exclusion of indirect evidence in China's law or practice. So far, no court practices such exclusion in any cases of undue correction.

Thirdly, remedies following violations of exclusionary rules are flawed. There are remedy procedures with regard to a possible use of undue coercion, as showed in Arts. 55 to 57 of the 2012 CPL in China. But without such procedures to remedy the right to silence, remedies following violations of exclusionary rules are incomplete and not workable. In China's criminal justice system, these articles 
only provide for a standard procedure for testing statements for the use of undue coercion. In law, the law enforcement authorities have the burden to prove whether or not undue coercion has been used when a confession or other statement was obtained. In practice, the actual situation on the burden of proof is quite diverse and not as good as expected in law.

In conclusion, it is very necessary for reformers and human rights defenders to promote further reforms on the right to silence and the admissibility of indirect evidence in order to exclude illegally obtained evidence in cases of undue coercion. Only if obstacles hampering the above reforms in law or practice are removed, China would finally fill in the gap between the actual implementation, limited to excluding any form of such evidence, and legal requirements for prohibiting torture in principle.

\section{Acknowledgement}

None.

\section{Conflict of Interest}

No conflict of interest. 